\title{
Effects of niacin and betaine on bovine mammary and uterine cells exposed to thermal shock in vitro
}

\author{
Y. Xiao, ${ }^{*}$ S. Rungruang,† L. W. Hall, ${ }^{*}$ J. L. Collier, ${ }^{*}$ F. R. Dunshea,ł and R. J. Collier ${ }^{* 1}$ \\ ${ }^{*}$ School of Animal and Comparative Biomedical Sciences, University of Arizona, Tucson 85721 \\ †Feed Technology, Charoen Pokphand Company, Bangkok, Thailand 10500 \\ ¥Faculty of Veterinary and Agricultural Sciences, University of Melbourne, Parkville, Victoria 3010, Australia
}

\section{ABSTRACT}

The objective of this study was to investigate the direct effects of feed supplements niacin and betaine on the heat shock responses of in vitro cultured cells derived from bovine mammary and uterine tissues. First, we determined the mRNA expression profiles of the niacin receptor (GPR109A) in bovine tissues (liver, skin, uterus, udder, and ovary) and in cells derived from bovine mammary epithelium (mammary alveolar cells, MAC-T; bovine mammary epithelial cells, BMEC) and endometrium (bovine endometrial cells, BEND). We found that GPR109A was distributed in all examined tissues and cells, and the highest expression was in cells from skin and udder. Second, we evaluated the effects of niacin treatment on the mRNA abundance of heat shock proteins 70 and 27 (HSP 70 and HSP27) in MAC-T, BMEC, and BEND under thermoneutral conditions and heat stress, and whether these effects were associated with alterations in the mRNA expression of prostaglandin $\mathrm{E}_{2}$ synthesis-related genes, including cyclooxygenase 1 and $2(C O X-1$ and $C O X-2)$ and microsomal prostaglandin E synthase 1 and 2 ( $m P G E S-1$ and $m P G E S$-2). Quantitative PCR data indicated that niacin suppressed $H S P 70$ mRNA expression in BMEC and both $H_{S P} 70$ and HSP27 in BEND under thermoneutral conditions. Only $C O X-2$ expression was downregulated by niacin in BMEC; other prostaglandin $\mathrm{E}_{2}$ synthesisrelated genes stayed unaltered in BMEC and BEND. The mRNA abundance of HSPro, COX-1, COX-2, and $m P G E S-1$ were elevated in niacin-treated MAC-T. During heat stress, niacin increased mRNA levels of HSP70 and HSP27 in MAC-T and HSP27 in BEND, but decreased HSP 70 in BMEC. Although mPGES-2 was stimulated by niacin in BEND, the mRNA expres-

\footnotetext{
Received August 16, 2016.

Accepted January 3, 2017.

${ }^{1}$ Corresponding author: rcollier@ag.arizona.edu
}

sion of prostaglandin $\mathrm{E}_{2}$ synthesis-related genes were consistent with neither $\mathrm{HSP}^{\mathrm{r}} 0$ nor $\mathrm{HSP}^{2} 7$ expression patterns in niacin-treated BMEC and MAC-T. These data suggest that the effects of niacin on heat shock protein expression and prostaglandin $\mathrm{E}_{2}$ synthesis were not well coupled in these cells. Finally, we tested the effects of betaine treatment on viability and apoptosis in BMEC. Compared with control cultures, viability was higher in betaine-treated cells at $8 \mathrm{~h}$ under thermoneutral conditions and at $16 \mathrm{~h}$ in heat stress, and apoptotic rates were lower at $8 \mathrm{~h}$. Our data support a dual role for niacin in regulating heat shock protein expression in normal and heat-shocked cells derived from mammary and uterine tissues, and positive effects of betaine in regulating mammary cell viability during heat stress.

Key words: heat shock, in vitro culture, GPR109A, prostaglandin $\mathrm{E}_{2}$, heat shock proteins

\section{INTRODUCTION}

Dairy cows are highly sensitive to heat stress due to their metabolic heat production during lactation and their limited cutaneous sweating capacity to evaporate heat loads (West, 2003; Gebremedhin et al., 2008). Heat stress triggers heat shock responses, alters global gene expression patterns, and causes structural and functional damage in mammary tissue and in vitro cultured mammary epithelial cells (Collier et al., 2006, 2008; Tao et al., 2011; Li et al., 2015). Altering dietary intake with supplements (e.g., niacin, yeast, buffers, and betaine) is an effective way to alleviate the negative effects of heat stress on production and on animal health (Beede and Collier, 1986; Dunshea et al., 2013; Rhoads et al., 2013). However, the direct effects of dietary supplements on the heat shock responses of specific tissues, such as mammary and uterine tissue, are poorly understood.

Niacin (also known as vitamin $\mathrm{B}_{3}$ ) reduces the incidence of metabolic disease and improves energy balance in dairy cows during the peripartum period (Kung et al., 1980; Dufva et al., 1983; Jaster and Ward, 1990; 
Schwab et al., 2005). However, the observed effects of niacin supplementation on heat-stressed dairy cows have not been consistent. Increased milk yield was associated with feeding $6 \mathrm{~g} / \mathrm{d}$ niacin in the summer (Muller et al., 1986), but 12, 24, or $36 \mathrm{~g} / \mathrm{d}$ supplemental niacin did not affect milk production during mild or severe heat stress in a later study (Di Costanzo et al., 1997). Using rumen-protected niacin increased niacin levels in the blood. However, its effects on core body temperature and milk production were variable and likely depended on the lactation stage of the cows and the severity of the heat stress (Zimbelman et al., 2010; Yuan et al., 2011; Lohölter et al., 2013; Zimbelman et al., 2013; Rungruang et al., 2014; Pineda et al., 2016). To elucidate niacin's effects, we need to understand how elevated circulating niacin levels affect the function of certain tissues. Niacin is known to bind to the GPR109A (or HCAR2) receptor (Wise et al., 2003; Titgemeyer et al., 2011). Niacin stimulates prostaglandin $\mathrm{D}_{2}\left(\mathbf{P G D}_{2}\right)$ and prostaglandin $\mathrm{E}_{2}\left(\mathbf{P G E}_{\mathbf{2}}\right)$ synthesis in Langerhans cells via this receptor, inducing skin flushing (Gille et al., 2008). Indeed, dietary supplements of niacin increased the evaporative heat loss of dairy cows exposed to elevated ambient temperatures (Zimbelman et al., 2010; Rungruang et al., 2014). Previous reports have shown the $\mathrm{PGD}_{2}$ - and $\mathrm{PGE}_{2}$-stimulated heat shock protein induction of in vitro cultured osteoblast-like cells (Kozawa et al., 2001; Tokuda et al., 2002). Because niacin also upregulates the synthesis of these molecules, we hypothesized that niacin could enhance cellular heat shock responses by promoting $\mathrm{PGD}_{2}$ and $\mathrm{PGE}_{2}$ synthesis via increased cyclooxygenase 1 or $2(\mathbf{C O X}-\mathbf{1}$ or COX-2) and prostaglandin E synthase gene expression in cells derived from mammary and uterine tissues.

Betaine (trimethylglycine) is a zwitterion that plays important roles in methyl group metabolism and stabilizing protein folding in cells under environmental stress (Craig, 2004; Lever and Slow, 2010). Dietary betaine supplementation alleviated the effects of heat stress on rectal temperature, respiration rate, and growth performance in rabbits (Hassan et al., 2011) and sheep (DiGiacomo et al., 2016). Carcass characteristics of feedlot cattle were also improved by dietary betaine during the summer, but heat shock protein expression was not altered in muscle and adipose tissues (DiGiacomo et al., 2014). Betaine supplementation increased the milk yield of dairy cows in thermoneutral conditions (Peterson et al., 2012; Hall et al., 2016) and heat stress (Zhang et al., 2014) in one study, but not in another (Hall et al., 2016). Heat shock protein expression was elevated in white blood cells and in vitro cultured mammary epithelial cells during heat stress (Hall et al., 2016). We hypothesized that betaine attenuates heat stress effects by increasing heat shock protein gene expression in mammary cells.

In this study, we hypothesized that niacin and betaine provide improved thermal tolerance via a common route: an increase in expression of heat shock genes. We also hypothesized that a niacin-induced increase in heat shock protein gene expression was caused by increased prostaglandin gene expression as a result of activation of the niacin receptor. First, we identified the expression of the niacin receptor GPR109A in different bovine tissues. Then, we evaluated the effects of niacin on the prostaglandin E synthase, cyclooxygenase, and heat shock gene responses of bovine mammary epithelial cells (BMEC) and endometrial cells. Finally, we investigated cell proliferation and apoptosis in betaine-treated BMEC under thermoneutral conditions and heat stress.

\section{MATERIALS AND METHODS}

\section{Cell Culture}

This study was conducted using a protocol approved by the Institutional Animal Care and Use Committee of the University of Arizona.

Mammary alveolar cells (MAC-T, gift from Wendie S. Cohick, Rutgers, the State University of New Jersey, New Brunswick) were derived from primary BMEC by immortalization using the SV40 large-T antigen (Sivaprasad et al., 2004). Cells were routinely maintained (passaged when confluency reached 80-90\%) in complete media consisting of Dulbecco's modified Eagle medium (DMEM; ThermoFisher Scientific, Grand Island, NY) supplemented with $3.7 \mathrm{~g} / \mathrm{L} \mathrm{NaHCO}_{3}$ (Sigma-Aldrich, St. Louis, MO), $10 \%$ fetal bovine serum (FBS, SigmaAldrich), $50 \mu \mathrm{g} / \mathrm{mL}$ gentamicin (Sigma-Aldrich), $5 \mu \mathrm{g} /$ $\mathrm{mL}$ bovine insulin (Sigma-Aldrich), and $10 \mathrm{~mL} / \mathrm{L}$ penicillin-streptomycin solution (ThermoFisher Scientific) at $37^{\circ} \mathrm{C}$ in a humidified atmosphere with $5 \% \mathrm{CO}_{2}$. Cells were plated on 24-well plates (Falcon, BD Bioscience, San Jose, CA; $0.5 \times 10^{5}$ cells/well) and grown for $24 \mathrm{~h}$ before applying treatments.

Bovine endometrial cells (BEND; gift from Thomas R. Hansen, Colorado State University, Fort Collins) were derived from bovine uterine endometrium (Staggs et al., 1998) and deposited in the American Type Culture Collection (ARCC no. CRL-2398, Manassas, VA). The BEND cells were passaged at a confluency of 60 to $70 \%$. Cells were plated on 24-well plates (Falcon, BD Bioscience; $0.5 \times 10^{5}$ cells/well) in culture medium containing 40\% Ham F12 (ThermoFisher Scientific), 40\% Minimum Essential Medium (ThermoFisher Scientific), $10 \%$ heat-inactivated FBS (Sigma-Aldrich), 10\% heat- 
inactivated horse serum (ThermoFisher Scientific), 8 $\mu \mathrm{g} / \mathrm{mL}$ insulin, $0.034 \mathrm{~g} / \mathrm{L}$ D-valine (Sigma-Aldrich), and $10 \mathrm{~mL} / \mathrm{L}$ antibiotic/antimycotic solution (ThermoFisher Scientific). Treatments were initiated $24 \mathrm{~h}$ after cells were plated. Prior to treatment application, the medium was refreshed in all wells.

Seeding mammary epithelial cells in a 3 -dimensional culture system provides a better way to analyze cellular function than the traditional monolayer method (Bissell et al., 2003; Wozniak et al., 2003). Mammary gland dissociation, isolation of primary BMEC, and preparation of type I collagen were performed according to (McGrath, 1987) with modifications (Collier et al., 2006; Hernandez et al., 2009) and cells were stored in liquid nitrogen until use. Cells were withdrawn from liquid nitrogen, spun, and resuspended in DMEM/Nutrient Mixture F12 (F12) medium (Sigma-Aldrich) to remove cryoprotectant, and cultured in 24-well plates as previously described (Hernandez et al., 2008; Stiening et al., 2008). Briefly, PBS and $\mathrm{NaOH}(0.75 N)$-neutralized collagen $(350 \mu \mathrm{L} /$ well $)$ were added to a tissue culture plate and left at room temperature for $20 \mathrm{~min}$ to serve as a base layer. The cell suspension was gently mixed with the collagen, added on top of the base layer $(500 \mu \mathrm{L} /$ well $)$, and incubated in a $5 \% \mathrm{CO}_{2}$ incubator at $37^{\circ} \mathrm{C}$ for $30 \mathrm{~min}$. The BMEC growth medium was then added to cultures in each well $(500 \mu \mathrm{L} /$ well $)$ and replaced with fresh medium every $2 \mathrm{~d}$ up to 6 to $8 \mathrm{~d}$. The growth medium consisted of serum-free DMEM/ F12 (Sigma-Aldrich), 0.1\% BSA (Sigma-Aldrich), 75 $\mathrm{ng} / \mathrm{mL}$ recombinant bovine insulin-like growth factor 1 (Monsanto, St. Louis, MO), $25 \mathrm{ng} / \mathrm{mL}$ recombinant human epidermal growth factor (ThermoFisher Scientific), $10 \mathrm{ng} / \mathrm{mL}$ insulin (Sigma-Aldrich), $5 \mathrm{ng} / \mathrm{mL}$ progesterone (Sigma-Aldrich), and $10 \mathrm{~mL} / \mathrm{L}$ of antibioticantimycotic solution (Thermo Fisher Scientific). Prior to treatment application, the medium was refreshed in all wells.

\section{RNA Isolation, DNase Treatment, and cDNA Synthesis}

Total RNA was prepared from tissue samples and cultured cells ( 2 wells of cells per sample) using TRIzol reagent according to the manufacturer's directions (ThermoFisher Scientific; https://tools.thermofisher. com/content/sfs/manuals/trizol_reagent.pdf). The RNA concentration was measured using a NanoDrop spectrophotometer (NanoDrop Technologies, Wilmington, DE). Extracted total RNA $(0.5 \mu \mathrm{g}$ of RNA per sample) was treated with DNase I (ThermoFisher Scientific) and then subjected to reverse transcription (Bio-Rad, Hercules, CA).

\section{Quantitative Real-Time PCR}

Quantitative real-time PCR (qPCR) was conducted using the iQ5 real-time PCR detection system (BioRad). Each qPCR mixture contained $5 \mu \mathrm{L}$ of cDNA, $10 \mu \mathrm{L}$ absolute blue SYBR green fluorescein (ThermoFisher Scientific), $0.5 \mu \mathrm{L}$ of forward and reverse primers $(10 \mu M)$, and PCR-grade $\mathrm{H}_{2} \mathrm{O}$ for a final volume of 25 $\mu \mathrm{L}$. The qPCR programs for each gene were as follows: heat activation of enzyme $\left(95^{\circ} \mathrm{C} / 15 \mathrm{~min}\right)$, amplification and quantification $\left(95^{\circ} \mathrm{C} / 10 \mathrm{~s}, 60^{\circ} \mathrm{C} / 45 \mathrm{~s}\right)$ for 40 cycles, and a melt curve program $\left(95^{\circ} \mathrm{C} / 60 \mathrm{~s}, 65^{\circ} \mathrm{C} / 60 \mathrm{~s}, 65\right.$ to $95^{\circ} \mathrm{C}$ at a rate of $\left.0.5^{\circ} \mathrm{C} / 10 \mathrm{~s}\right)$. Primer sequences are shown in Table 1 . The cDNA samples were measured in triplicate and threshold cycles $\left(\mathbf{C}_{\mathbf{t}}\right)$ normalized to a reference gene using the comparative $\Delta \mathrm{C}_{\mathrm{t}}$ method, and fold changes $\left(2^{-\Delta \Delta \mathrm{Ct}}\right)$ were determined using the Livak method (Livak and Schmittgen, 2001). In experiments 1 and 2, RPS9 was chosen as the reference gene due to its stable expression among tested tissues and cell samples, with or without treatments.

\section{Terminal Deoxynucleotidyl Transferase dUTP Nick End Labeling}

Terminal deoxynucleotidyl transferase dUTP nick end labeling (TUNEL) of the free 3 '-OH DNA termini with modified nucleotides in situ allows us to visualize endonucleolytic DNA fragmentation in cells undergoing apoptosis. Collagen gels were broken down with $0.1 \%$ collagenase I (Worthington Biochemical Corp., Lakewood, NJ) as previously described (Hernandez et al., 2009). The collected cell pellet was broken by pipetting up and down and digested with $0.25 \%$ trypsinEDTA (25200; Invitrogen, Carlsbad, CA) at $37^{\circ} \mathrm{C}$ for 3 to 4 min. After being washed twice with PBS (with $5 \%$ FBS), cells were resuspended with $100 \mu \mathrm{L}$ of PBS. The TUNEL assay was performed using the ApopTag peroxidase in situ apoptosis detection kit (Chemicon International, Temecula, CA). The manufacturer's protocol (https://www.emdmillipore.com/US/en/product/ApopTag-Peroxidase-In-Situ-Apoptosis-DetectionKit,MM_NF-S7100\#anchor_UG) was followed, with some modifications as previously described (Annen et al., 2007). Developing color in peroxidase substrate was performed using a DAB peroxidase substrate kit (Vector Laboratories, Burlingame, CA). Mounted slides were observed under a light microscope (Leica DM5500B, Buffalo Grove, IL).

\section{Cell Viability and Proliferation Assay}

A tetrazolium salt, sodium 3'-[1-[(phenylamino)carbonyl]-3,4-tetrazolium]-bis (4-methoxy-6-nitro) 
benzene-sulfonic acid hydrate (XTT), was used to evaluate cell viability and metabolic activity (Roehm et al., 1991). The XTT can be reduced by mitochondrial dehydrogenases of viable cells yielding an orange, water-soluble formazan derivative that can be detected spectrophotometrically. The XTT assay was performed using a commercial kit (Roche Applied Science, Indianapolis, IN) after the treatment was finished, and the protocol was adapted from a recent report (Huyck et al., 2012). The medium in every well, including no-cells blanks, was replaced with $300 \mu \mathrm{L}$ of fresh medium, and then $200 \mu \mathrm{L}$ of XTT labeling mixture was applied. Cell culture plates were incubated at $37^{\circ} \mathrm{C}$ for $8 \mathrm{~h}$. Absorbance at both $450 \mathrm{~nm}$ and $690 \mathrm{~nm}$ for 3D cultures was measured using a SpectraMax M2 plate reader (Molecular Devices, Sunnyvale, CA). Net absorbance (A) of sample measured by the plate reader was calculated using the following formula: Absorbance $=\mathrm{A}_{450-690 \mathrm{~nm}}-$ mean $\left(\mathrm{A}_{\text {blank }}\right)$.

\section{Experimental Design}

Experiment 1: Distribution of Niacin Receptor in Bovine Tissues and Cells. To identify the expression of niacin receptor GPR109A in bovine tissues and cells, reverse-transcription PCR was performed on RNA samples from the tissues of 3 cows (liver, uterus, ovary, skin, and udder), and from 3 types of cells (BEND, MAC-T, and BMEC). Expression levels of GPR109A were compared among tissues using qPCR.

Experiment 2: Effects of Niacin Treatment on Heat Shock Responses of Bovine Cells. All 3 cell types were subjected to niacin (Sigma-Aldrich) treatment at 0 or $0.01 \mathrm{~m} M(1.23 \mu \mathrm{g} / \mathrm{mL})$, and exposed to thermoneutral conditions $\left(37^{\circ} \mathrm{C}\right)$ or heat stress $\left(42^{\circ} \mathrm{C}\right)$ for $8 \mathrm{~h}$. The dose of niacin used matched niacin levels in the plasma of cows (Rungruang et al., 2014). Cells were cultured in 24-well plates. Two wells of cells were pooled for 1 sample, and 3 samples stood for each dose and environment. The mRNA expression of heat shock proteins ( $\mathrm{HSP}^{\mathrm{r}} 0$ and $\mathrm{HSP}^{2} \mathrm{y}$ ) and prostaglandin $\mathrm{E}$ synthesis-related enzymes (COX-1, COX-2, mPGES-1 and $m P G E S-2)$ were evaluated in MAC-T, BMEC, and $B E N D$. The $C_{t}$ values of the genes of interest were normalized with those of reference gene RPS9.

Experiment 3: Effects of Betaine Treatment on Cell Viability and Apoptosis of Primary BMEC During Heat Stress. To determine the effects of betaine on cell proliferation or viability, the XTT assay was performed on BMEC treated with 0 or $25 \mathrm{mM}$ $(2.93 \mathrm{mg} / \mathrm{mL}$ ) betaine (PureBulk, Roseburg, OR) in thermoneutral conditions and heat stress at $0,8,16$, and $24 \mathrm{~h}$. The dosage for betaine treatment was taken from previous cell culture studies in mice, which reported that $25 \mathrm{~m} M$ betaine enhanced cell growth under osmotic stress (Petronini et al., 1992; Petronini et al., 1993). Three replicates were used for each treatment, environment, and time point. No-cells blanks were designed in every cell culture plate. Cell viability at $0 \mathrm{~h}$ was set as $100 \%$.

To investigate the effects of betaine on heat-induced apoptosis, the TUNEL assay was performed on BMEC treated with 0 or $25 \mathrm{~m} M$ betaine in thermoneutral conditions or heat stress for $8 \mathrm{~h}$. Two wells of BMEC were collected for 1 sample, and 3 replicates stood for each treatment and temperature. Three slides of cells were prepared from each sample for the assay. At least 300 cells from at least 10 fields in each slide were counted,

Table 1. Primer sequences $(\mathrm{F}=$ forward, $\mathrm{R}=$ reverse)

\begin{tabular}{|c|c|c|c|}
\hline Gene & Accession number & Primer $\left(5^{\prime}-3^{\prime}\right)$ & Reference \\
\hline$C O X-2$ & NM_174445 & $\begin{array}{l}\text { F: TCCACCAACTTATAATGTGCAC } \\
\text { R: GGCAGTCATCAGGCACAGGA }\end{array}$ & Saint-Dizier et al., 2011 \\
\hline GPR $109 A^{1}$ & XM_015475510.1 & $\begin{array}{l}\text { F: ACATCACCCTCAGCTTCACC } \\
\text { R: GCGGTTGTTATCCGACTCAT }\end{array}$ & Titgemeyer et al., 2011 \\
\hline$H P R T$ & NM_001034035.2 & $\begin{array}{l}\text { F: GAGAGTCCGAGTTGAGTTTGGAA } \\
\text { R: GGCTCGTAGTGCAAATGAAGAGT }\end{array}$ & \\
\hline HSP70 & NM_203322.2 & $\begin{array}{l}\text { F: CGTGCTCATCTTTGATCTGG } \\
\text { R: TGGCTGATGTCCTTCTTGTG }\end{array}$ & \\
\hline$m P G E S-1$ & NM_174443.2 & $\begin{array}{l}\text { F: TCCTGGGCTTTGTCTACTCT } \\
\text { R: CAGTTTCCCCAGGTATGCCAC }\end{array}$ & \\
\hline$m P G E S-2$ & AY692441.1 & $\begin{array}{l}\text { F: CCTCCTACAGAAAGGTGCC } \\
\text { R: GTGATGATGTCTGCCAGGG }\end{array}$ & \\
\hline
\end{tabular}

\footnotetext{
${ }^{1}$ Also known as hydroxycarboxylic acid receptor 2 (HCAR2) in cattle.
} 
and the percentage of apoptotic cells was calculated for each slide.

\section{Statistical Analysis}

All statistical analyses were conducted with the PROC MIXED procedure (SAS 9.4; SAS Institute, Cary, NC), except that we used PROC CORR for correlation analysis of $\mathrm{HSP}^{\mathrm{r}} \mathrm{O}$ and $\mathrm{COX}$-2 expression in BMEC at thermoneutral conditions. To compare GPR109A mRNA expression in different tissues, the model included the main effect of tissues. The fixed effects of treatment, environment, and their interaction were included in the model of experiment 2, as well as in the TUNEL assay in experiment 3. The model for gene expression and XTT assay in experiment 3 included treatment, environment, time, treatment $\times$ environment, treatment $\times$ time, and treatment $\times$ environment $x$ time. Replications in all experiments were considered as random effects. Tukey adjustment was used for multiple comparisons. For gene expression data, the $\Delta \mathrm{C}_{\mathrm{t}}$ values were used for statistical analysis, and the fold changes $\left(2^{-\Delta \Delta \mathrm{Ct}}\right)$ were presented in figures, because the $C_{t}$ values were observed values that should be subjected to statistical analysis (Yuan et al., 2006). The gene expression data were reported as means \pm standard error and considered to be different when $P$ $<0.05$. In the XTT and TUNEL assays, data were reported as least squares means \pm standard error.

\section{RESULTS}

\section{Experiment 1: Distribution of Niacin Receptor in Bovine Tissues and Cells}

The mRNA expression of niacin receptor GPR109A was detected in liver, skin, uterus, udder, and ovary tissues, as well as in BEND, BMEC, and MAC-T (Figure 1A). The qPCR of tissue samples showed that GPR109A mRNA expression in skin and udder was 26.41- and 4.37-fold higher than in liver, respectively $(P$ $<0.01$, Figure 1B). We observed no difference between liver, uterine, and ovary tissue. These data indicated that niacin signaling might affect skin and mammary tissues more than others.

\section{Experiment 2: Effects of Niacin Treatment on Heat Shock Responses of Bovine Cells}

Under thermoneutral conditions, $8 \mathrm{~h}$ of niacin treatment enhanced the mRNA expression of $\mathrm{HSP}^{\mathrm{r}} \mathrm{O}$ in MAC-T cells $(P<0.05)$, but the abundance of $H S P 70$ mRNA in BMEC and BEND and of HSP27 mRNA in BEND were decreased by niacin treatment $(P<0.01$,
Figure 2). During heat stress, both HSP70 and HSP27 mRNA levels were increased by $8 \mathrm{~h}$ of elevated temperature $(P<0.01)$ in control BMEC and BEND, but not in control MAC-T, indicating that the complete attenuation of heat shock responses in MAC-T might take place earlier than in the other 2 types of cells. Niacin stimulated the mRNA expression of $\mathrm{HSP}^{\mathrm{r}} \mathrm{O}$ and HSP27 in MAC-T $(P<0.01)$ and HSP27 in BEND $(P<0.05)$, but the mRNA expression of HSP70 was attenuated in BMEC $(P<0.01$, Figure 2$)$. These data suggest that environmental temperature and cell type could alter the effects of niacin on heat shock protein expression in bovine cells.

To investigate whether niacin regulated heat shock protein expression by controlling $\mathrm{PGH}_{2}$ synthesis and $\mathrm{PGE}_{2}$ terminal synthesis, we evaluated the effects of niacin treatment on the mRNA expression of $C O X-1$, COX-2, mPGES-1, and mPGES-2 in MAC-T, BMEC, and BEND. The qPCR data showed that the mRNA abundance of $C O X-1, C O X-2$, and $m P G E S-1$ was ele-
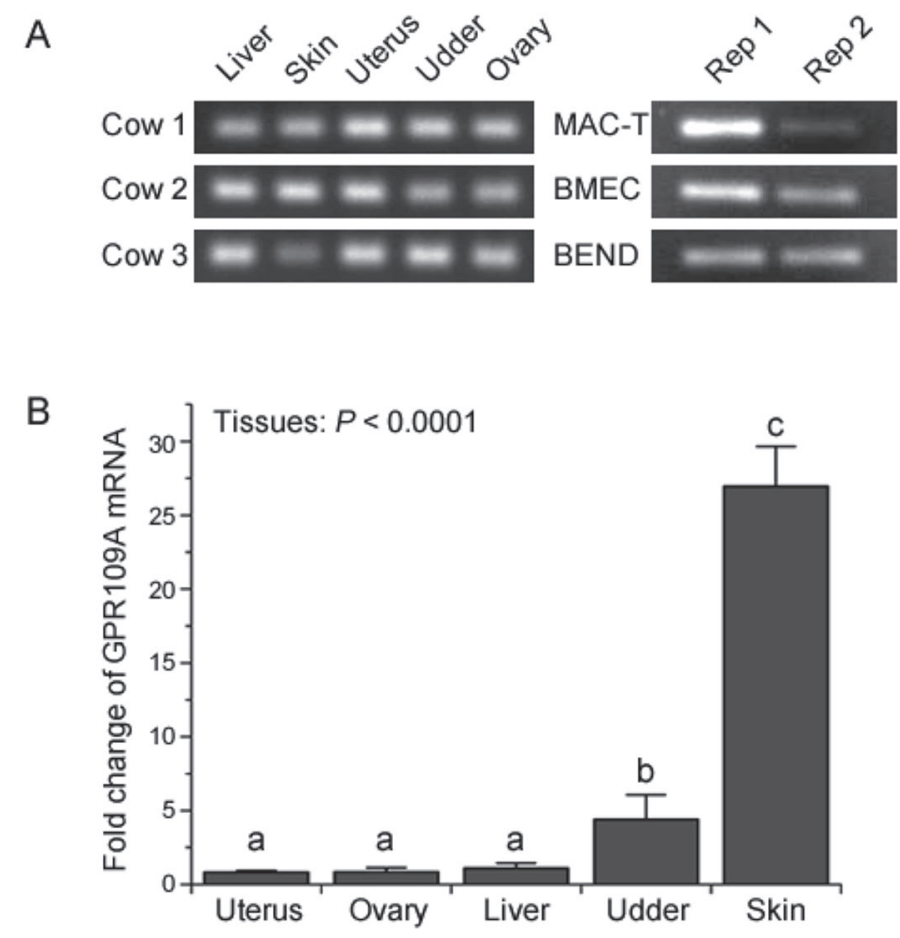

Figure 1. Abundance of niacin receptor GPR109A mRNA in bovine tissues and in mammary alveolar cells (MAC-T), bovine mammary epithelial cells (BMEC), and bovine endometrial cells (BEND). (A) Reverse-transcription PCR analysis of GPR109A mRNA expression in indicated tissue samples collected from 3 cows and 3 types of cells with 2 replicates (Rep) for each. (B) Quantitative PCR assay on mRNA expression of GPR109A in tissue samples. Fold change of gene expression levels was calculated using the $2^{-\Delta \Delta \mathrm{Ct}}$ method, with the liver as the calibrator. Data are represented as means $\pm \mathrm{SE}(\mathrm{n}=3)$; different letters $(\mathrm{a}-\mathrm{c})$ indicate significant differences $(P<0.05)$. 

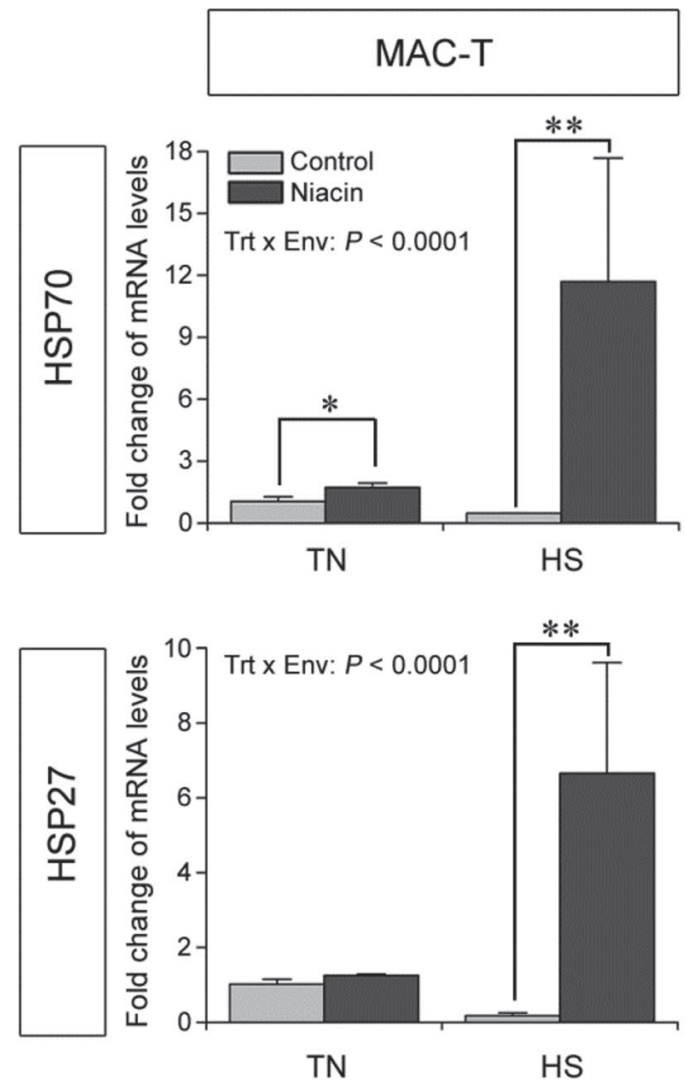
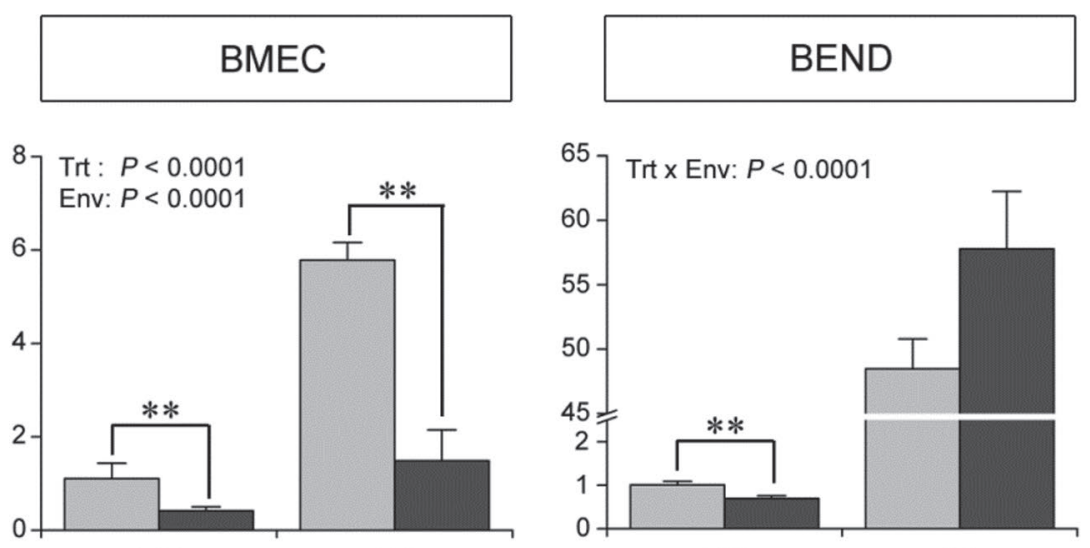

TN

HS

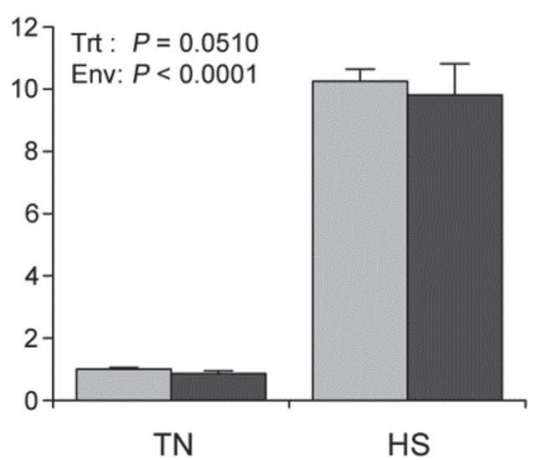

Figure 2. Effects of niacin treatment on heat shock responses of bovine cells derived from the mammary glands (mammary alveolar cells, MAC-T; bovine mammary epithelial cells, BMEC) and the uterus (bovine endometrial cells, BEND). Quantitative PCR of HSP 70 and HSP27 was conducted on niacin-treated or control cells exposed to thermoneutral conditions $\left(\mathrm{TN}, 37^{\circ} \mathrm{C}\right)$ or heat stress $\left(\mathrm{HS}, 42^{\circ} \mathrm{C}\right)$ for 8 h. Fold change of mRNA expression levels was calculated using the $2^{-\Delta \Delta \mathrm{Ct}}$ method, with the control cells in TN as the calibrator. Data are represented as means $\pm \mathrm{SE}(\mathrm{n}=3)$. Trt = treatment; Env = environment. Differences were observed between control and niacin within the same environment; ${ }^{*} P$ $<0.05 ;{ }^{* *} P<0.01$.

vated $(P<0.01)$ by niacin treatment in MAC-T exposed to thermoneutral conditions (Figure 3), suggesting that $\mathrm{PGH}_{2}$ and $\mathrm{PGE}_{2}$ synthesis might be enhanced by niacin in these cells. In contrast, $C O X-2$ was downregulated by niacin $(P<0.01)$ in BMEC under thermoneutral conditions, but $m P G E S-1$ and $m P G E S$-2 were not affected. During heat stress, niacin enhanced $(P<0.01)$ COX-1 and mPGES-2 mRNA expression in BMEC and BEND (Figure 3), respectively, suggesting that $\mathrm{PGE}_{2}$ synthesis might be stimulated in niacin-treated and heat-shocked cells. These data indicate a dual role of niacin in $\mathrm{PGE}_{2}$ synthesis under thermoneutral conditions and heat stress.

\section{Experiment 3: Effects of Betaine Treatment on Cell Viability and Apoptosis of Primary BMEC During HS}

During analysis of previous data sets (Hall et al., 2016), we noticed that the expression of $H S P^{r} 0 \mathrm{mRNA}$ remained higher $(P<0.01)$ in betaine-treated cells than in controls after $8 \mathrm{~h}$ of exposure to $42^{\circ} \mathrm{C}$ (Figure
4A). Therefore, we investigated whether the elevated HSP 70 in betaine-treated cells could alleviate the negative effects of heat stress. The XTT assay results showed that the viability of BMEC was affected by treatment $\times$ temperature $\times$ time $(P<0.01)$. Under thermoneutral conditions, cell viability was increased $(P<0.01)$ by betaine treatment at $8 \mathrm{~h}$ but not at other time points (Figure 4B). During heat stress, cell viability significantly declined $(P<0.01)$. Compared with control cells, the viability of betaine-treated cells was higher at $16 \mathrm{~h}(P<0.01$; Figure $4 \mathrm{~B})$. Together, these data indicate that betaine had positive effects on cell proliferation under thermoneutral conditions and extended cell viability in heat stress.

The TUNEL assay showed that the percentage of apoptotic BMEC was elevated after $8 \mathrm{~h}$ of heat stress compared to thermoneutral conditions $(P<0$. 01). Betaine treatment decreased the apoptosis rate of heat-shocked BMEC $(P<0.01$; Figure $4 \mathrm{C})$, indicating that betaine may protect cells in heat stress through antiapoptotic effects. 


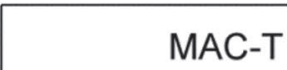

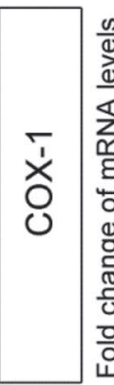
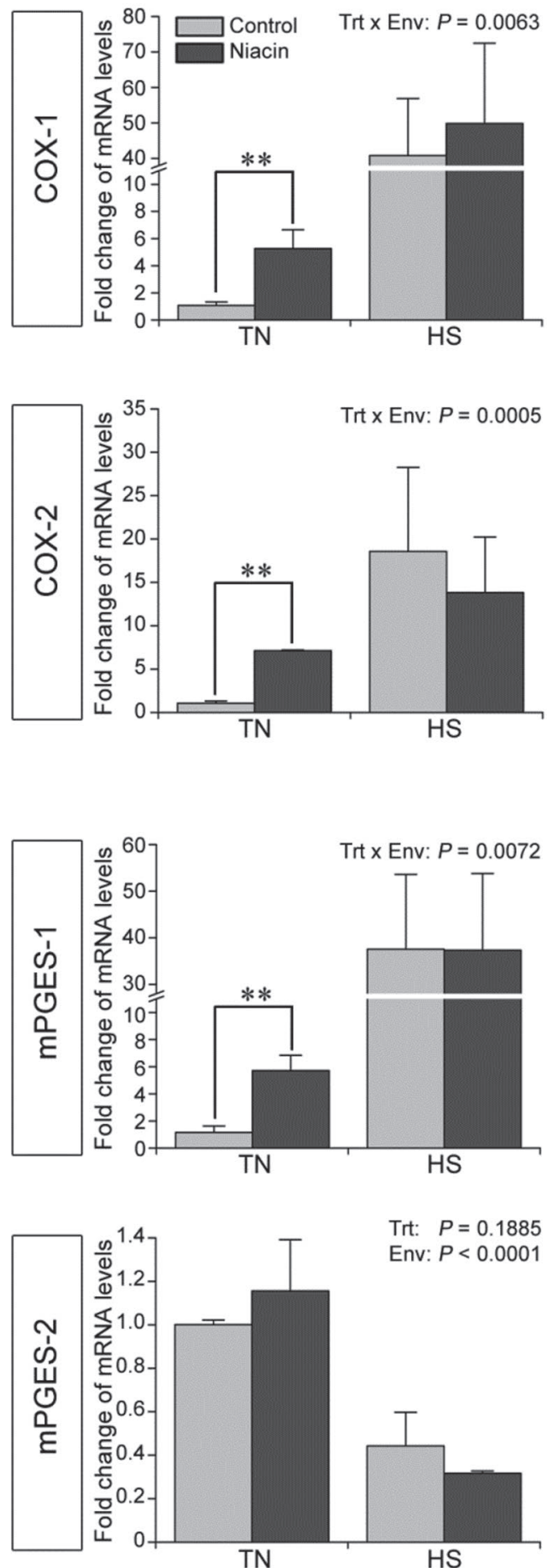
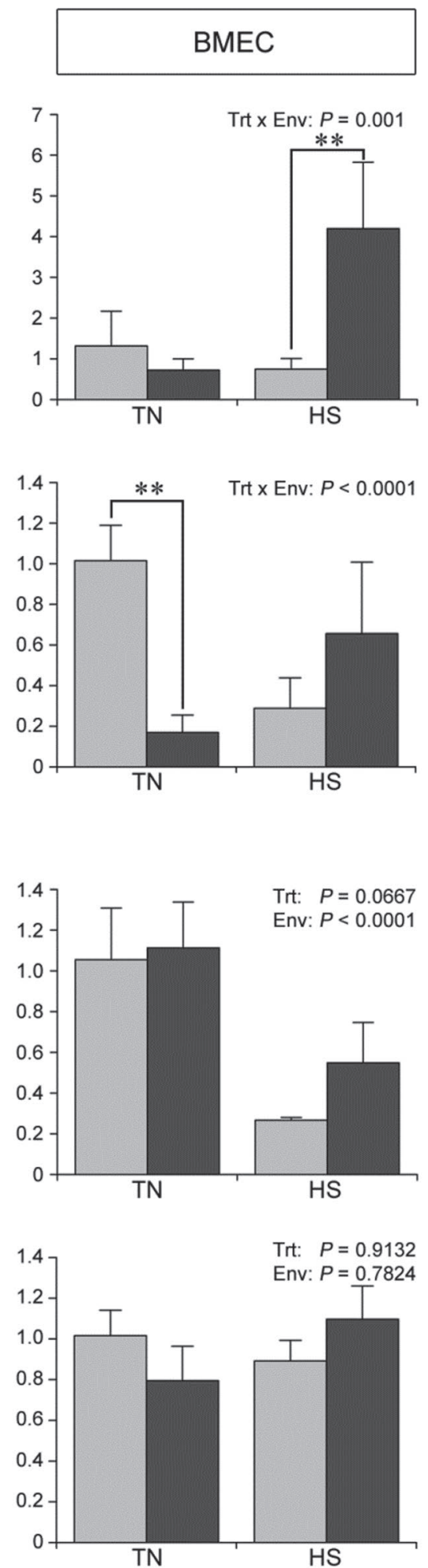
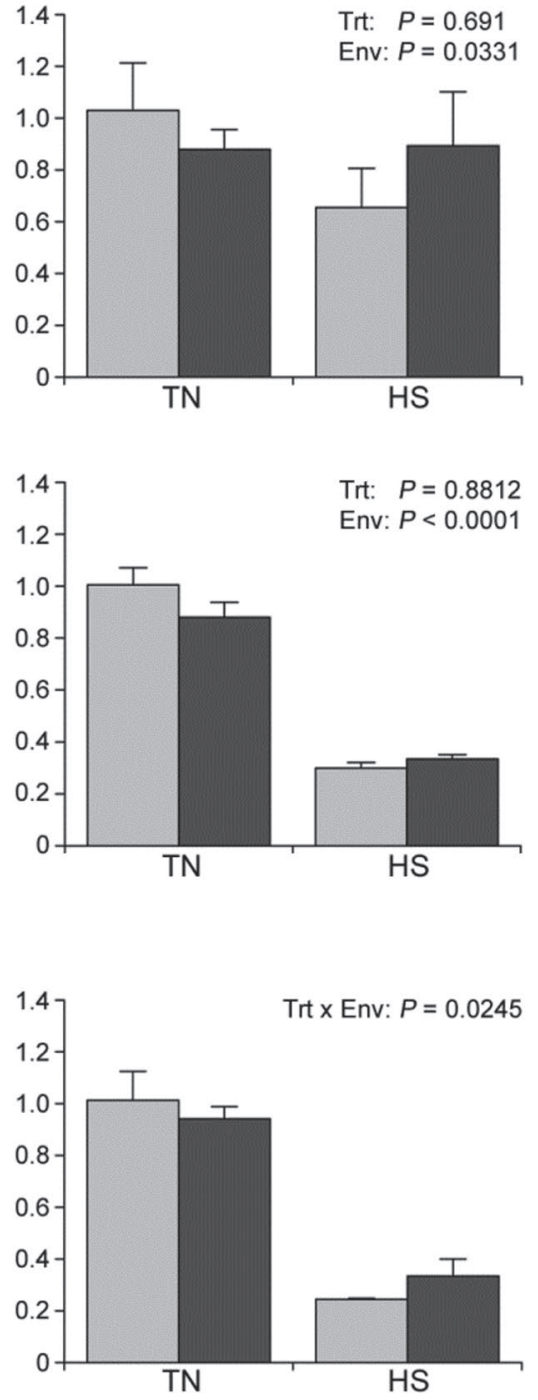

Trt: $P=0.8812$ Env: $P<0.0001$

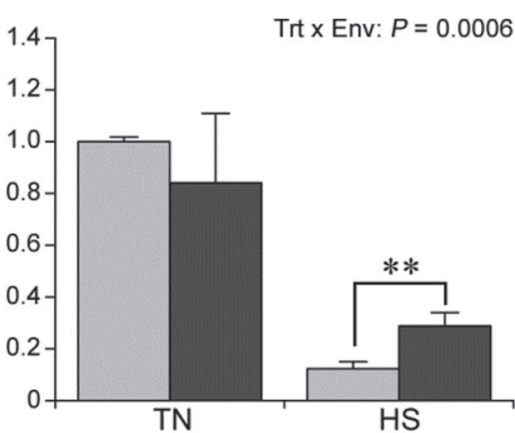

Figure 3. Effects of niacin treatment on mRNA expression of prostaglandin $\mathrm{E}_{2}$ synthesis-associated genes in mammary alveolar cells (MAC-T), bovine mammary endothelial cells (BMEC) and bovine endometrial cells (BEND). Quantitative PCR of $C O X-1, C O X$-2, $m P G E S-1$, and $m P G E S$-2 was performed on niacin-treated or control cells exposed to thermoneutral conditions $\left(\mathrm{TN}, 37^{\circ} \mathrm{C}\right)$ or heat stress $\left(\mathrm{HS}, 42^{\circ} \mathrm{C}\right)$ for $8 \mathrm{~h}$. Fold change of mRNA expression levels was calculated using the $2^{-\Delta \Delta \mathrm{Ct}}$ method, with the control cells in TN as the calibrator. Data are represented as means $\pm \mathrm{SE}(\mathrm{n}=3)$. Trt $=$ treatment; Env = environment. Differences were observed between control and niacin within the same environment; ${ }^{* *} P<0.01$. 
A
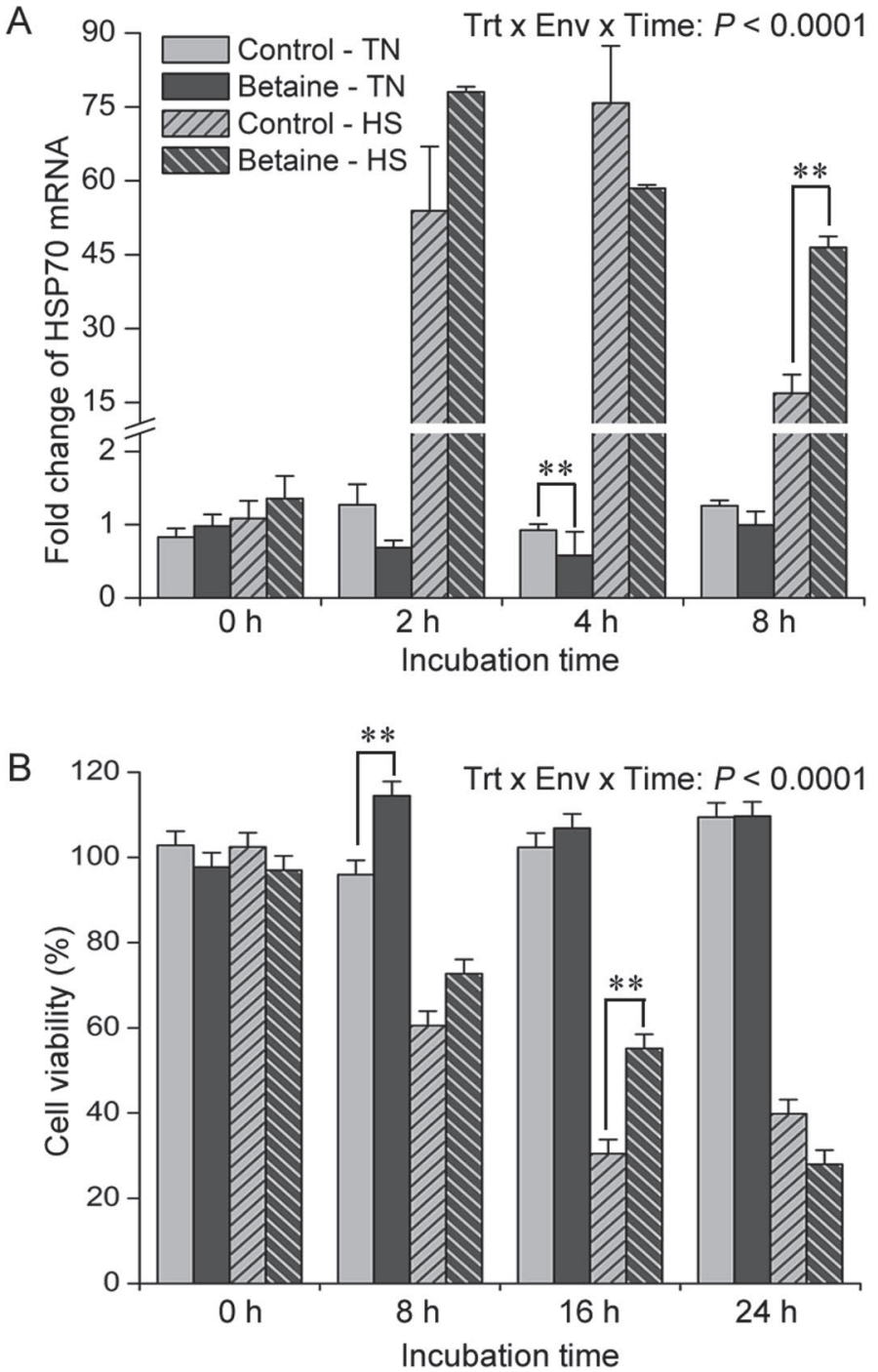

Trt x Env x Time: $P<0.0001$
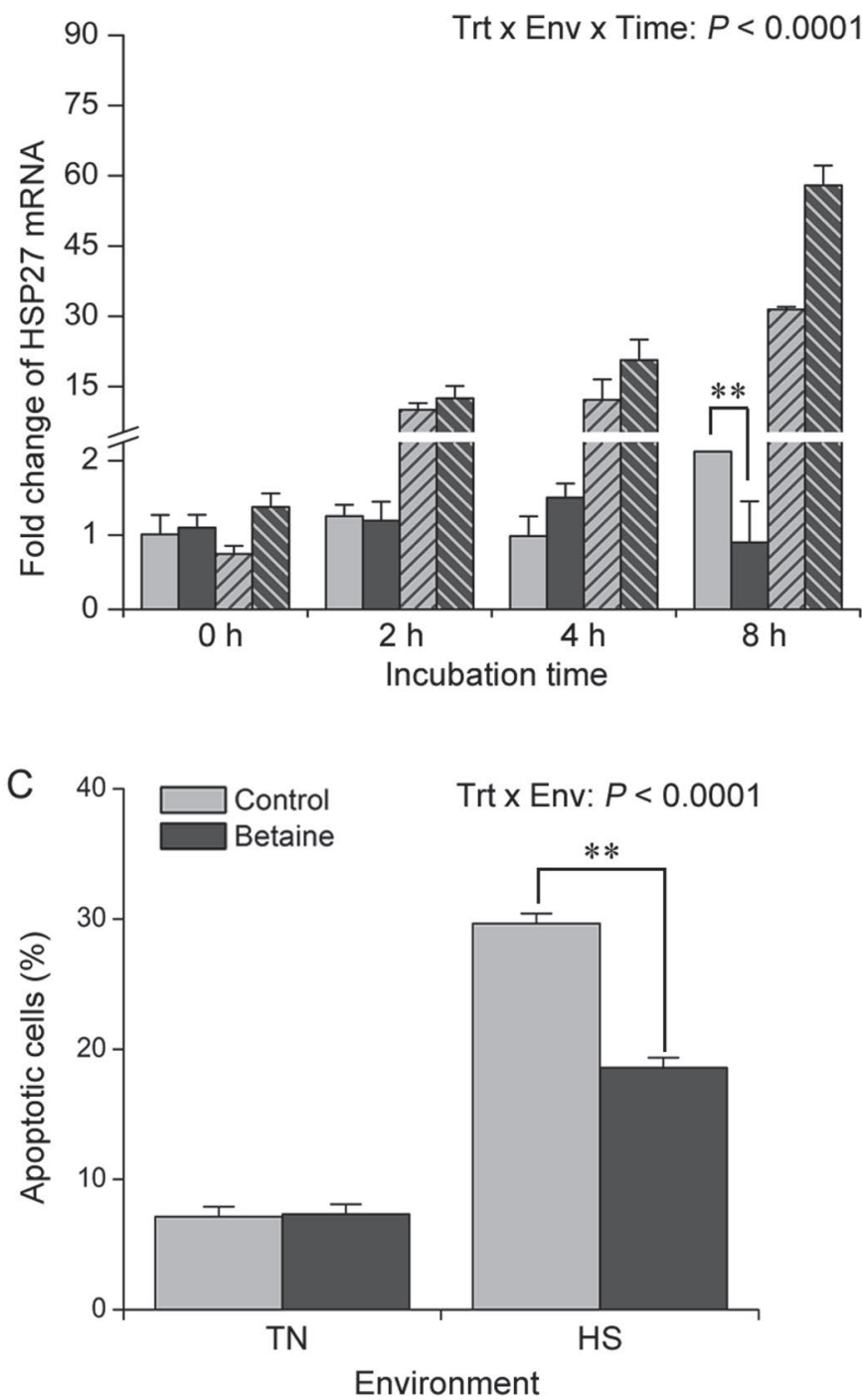

Figure 4. Effects of betaine treatment on heat shock responses, viability, and apoptosis in bovine mammary epithelial cells. (A) HSPro (left) and HSP27 (right) mRNA expression of control and betaine-treated cells in thermoneutral conditions $\left(\mathrm{TN}, 37^{\circ} \mathrm{C}\right)$ or heat stress $\left(\mathrm{HS}, 42^{\circ} \mathrm{C}\right)$ at different time points were investigated using quantitative PCR. Hypoxanthine phosphoribosyltransferase $(H P R T)$ served as the reference gene. Fold change of mRNA expression levels was calculated using the $2^{-\Delta \Delta \mathrm{Ct}}$ method, with the averaged $\Delta \mathrm{C}_{\mathrm{t}}$ value of samples at $0 \mathrm{~h}$ as the calibrator. Data are represented as means $\pm \mathrm{SE}(\mathrm{n}=3)$, and were adapted from our previous report (Hall et al., 2016). (B) Cell viability was measured using sodium 3'-[1-[(phenylamino)-carbonyl]-3, 4-tetrazolium]-bis (4-methoxy-6-nitro) benzene-sulfonic acid hydrate (XTT) assay. Control and betaine-treated cells were placed in TN and HS for $0,8,16$, or $24 \mathrm{~h}$ and then subjected to the XTT assay. The averaged optical density value of the samples at $0 \mathrm{~h}$ was set at $100 \%$. Data are represented as least squares means $\pm \mathrm{SE}(\mathrm{n}=3)$. (C) Apoptotic cell rates of control and betainetreated cells in $8 \mathrm{~h}$ of TN and HS determined using the terminal deoxynucleotidyl transferase dUTP nick-end labeling (TUNEL) assay. Data are represented as least squares means $\pm \mathrm{SE}(\mathrm{n}=3)$. Trt $=$ treatment; Env = environment. Differences were observed between control and betaine within the same environment; ${ }^{* *} P<0.01$.

\section{DISCUSSION}

We evaluated the effects of niacin and betaine on the cellular heat shock responses of 3 types of bovine cells derived from mammary glands and uterine tissues. We found that mammary tissues had the second-highest niacin receptor mRNA expression among uterus, ovary, liver, udder, and skin. Niacin downregulated the
mRNA expression of $\mathrm{HSP}^{\mathrm{T}} \mathrm{O}$ in BMEC and BEND and HSP27 in BEND under thermoneutral conditions. In heat stress, niacin upregulated the mRNA expression of HSP70 in MAC-T and of HSP27 in MAC-T and BEND, but it decreased expression of HSPrO in BMEC. The mRNA expression patterns of $\mathrm{PGE}_{2}$ synthesis-related genes indicated that niacin might not regulate heat shock protein expression by altering $\mathrm{PGE}_{2}$ synthesis. 
Table 2. Niacin effects ${ }^{1}$ on mRNA expression of heat shock proteins and prostaglandin $\mathrm{E}_{2}$ synthesis-related genes under thermoneutral conditions and heat stress ${ }^{2}$

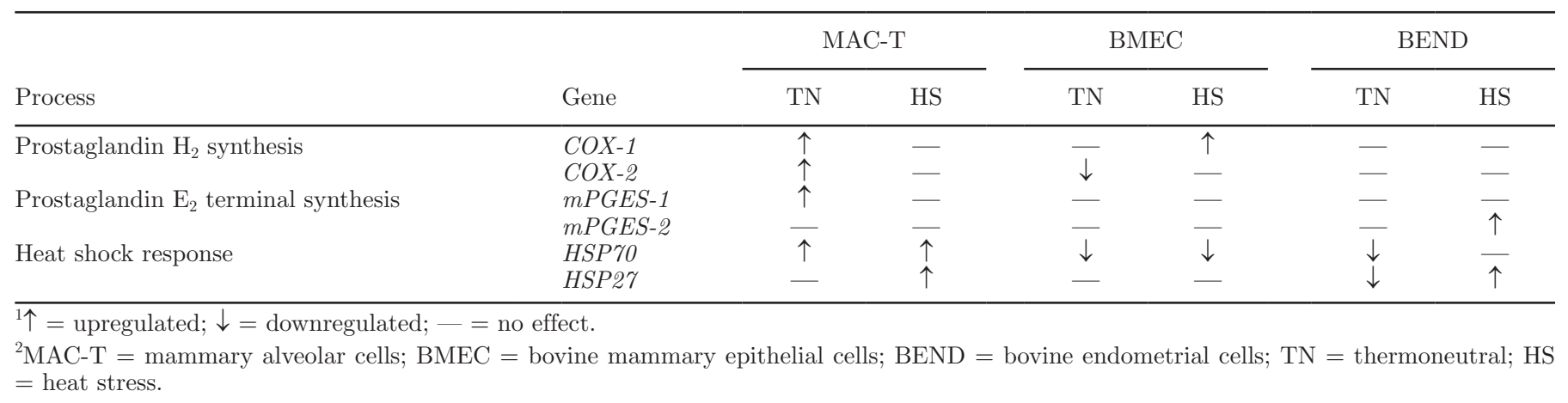

However, we did not measure the protein abundance of heat shock protein in this study, so we do not know if actual protein concentrations were changed or not. Betaine provided limited protection for mammary epithelial cells as measured by reduced apoptotic rates at $8 \mathrm{~h}$ and improved viability only at $16 \mathrm{~h}$.

The niacin receptor GPR109A distributes variously in different tissues of mammals, including rodents, cats, cattle, and human (Offermanns et al., 2011; Titgemeyer et al., 2011; Graff et al., 2015). The distribution of GPR109A in tissues is usually associated with the importance of its agonists. For instance, niacin is well known for inducing flushing, inhibiting lipolysis, and activating immune cells (Offermanns et al., 2011; Rahman et al., 2014). Correspondingly, GPR109A abundantly distributes in skin, adipose, and immune organs or cells (Maciejewski-Lenoir et al., 2006; Bermudez et al., 2011). Previous analysis of the expression patterns of GPR109A indicated that bovine adipose tissues had lower abundance than liver (Titgemeyer et al., 2011). Our data demonstrated that mammary tissues expressed GPR109A mRNA at levels even higher than liver, indicating that GPR109A pathways could be involved in regulating mammary function. Recently, the expression of GPR109A was identified in human mammary tissues and mammary epithelial cells, and involved in suppressing breast cancer (Elangovan et al., 2014). Collectively, the mRNA abundance of GPR109A suggested that bovine mammary glands might be competent for activation by its agonists.

Niacin has been well characterized for inducing COX-1-dependent $\mathrm{PGD}_{2}$ and $\mathrm{PGE}_{2}$ production in Langerhans cells and COX-2-dependent $\mathrm{PGE}_{2}$ synthesis in keratinocytes (Hanson et al., 2010). In this study, we verified similar effects of niacin in MAC-T cells under thermoneutral conditions (Table 2). Moreover, the expression of $\mathrm{HSP}^{\mathrm{r}} 0$ was stimulated in responding to elevated $C O X-1, C O X-2$, and $m P G E S-1$ (Table 2 ). These data partially supported our hypothesis that niacin could enhance heat shock response by regulating $\mathrm{PGE}_{2}$ synthesis. At the same temperature, however, the effects of niacin on regulating gene expression were not consistent in the other cell types, BMEC and BEND (Table 2). The MAC-T cells used in this study were derived from the mammary glands of lactating cows and immortalized in vitro (Huynh et al., 1991), suggesting that MAC-T cells were composed mainly of fully differentiated alveolar cells. The BMEC cells used were isolated from the mammary epithelium of pregnant cows (6 to 7 mo gestation) and cultured in vitro without cell passage. Therefore, MAC-T and BMEC were probably not at the same stage of development. This might have contributed to their different responses to niacin treatment, because signaling pathways have distinct effects on mammary glands at different developmental stages (Macias and Hinck, 2012).

We found that niacin depressed $C O X-2$ expression in BMEC under thermoneutral conditions, and this was in line with previous studies conducted in other cell types. In mouse adipocytic 3T3-L1 cells, niacin suppressed COX-2 expression and resulted in depressed production of $\mathrm{PGF}_{2 \alpha}$ during adipogenesis (Fujimori and Amano, 2011). Downregulation of CCAAT enhancer-binding protein $\beta(\mathbf{C} / \mathbf{E B P} \boldsymbol{\beta})$ by niacin treatment was responsible for decreased $C O X$-2 in adipocytes (Fujimori and Amano, 2011), considering that COX-2 expression is controlled by $\mathrm{C} / \mathrm{EBP} \beta$ (Lee et al., 2005; Healy et al., 2008). It was noted that $\mathrm{C} / \mathrm{EBP} \beta$ was expressed in human and mouse mammary epithelial cells and played important roles in mammary gland development (Seagroves et al., 1998; Dearth et al., 2001; Bundy and Sealy, 2003). Here, we showed that COX-2 mRNA expression was downregulated by niacin treatment in primary cells isolated from bovine mammary glands, supporting the notion that $C O X-2$ could be negatively regulated by niacin. We speculate that $\mathrm{C} / \mathrm{EBP} \beta$ was involved in niacin-induced $C O X-2$ downregulation in mammary epithelial cells in a thermoneutral environ- 
ment. Although the expression of $\mathrm{COX}-2$ and $\mathrm{HSP}^{\mathrm{r}} \mathrm{O}$ were positively correlated, it was still unclear how HSP70 expression was suppressed by niacin. Production of $\mathrm{PGE}_{2}$ was unlikely involved in this process, because $m P G E S$-2 expression was not affected by niacin in this study. The expression of HSP7O is inducible under stress through binding of activated $H S F 1$ on the heat shock elements in the HSP70 promoter (Wu, 1995). Under unstressed conditions, the promoter activity of HSP70 was regulated by other factors, including TATA factors, CCAAT-binding factors, and SP1 (Greene et al., 1987). However, little evidence so far suggests that niacin can regulate $\mathrm{HSP}^{\mathrm{r}} \mathrm{O}$ via these 3 factors. The effects of niacin-induced downregulation of heat shock protein on cellular functions in mammary and uterine cells needs to be further elucidated in future studies.

During heat stress, the expression of $\mathrm{HSP}^{2} \mathrm{y}^{7}$ was stimulated by niacin treatment in BEND. Given that the abundance of $m P G E S$ - 2 mRNA was also elevated in niacin-treated $\mathrm{BEND}, \mathrm{PGE}_{2}$ production could be involved in the upregulation of HSP2\%. Indeed, a previous study showed that $\mathrm{PGE}_{2}$ boosted HSP27 expression without affecting $H S P 70$ expression levels in osteoblasts (Tokuda et al., 2002). This process was mediated by the activation of protein kinase $\mathrm{C}$, which activated both p44/p42 MAP kinase and p38 MAP kinase (Tokuda et al., 2002). In the present study, mRNA expression of $C O X-1$ and $C O X-2$ was not affected by niacin treatment (Table 2), so niacin-induced $m P G E S$-2 expression seemed not to be driven by $C O X-1$ or $C O X$ 2 in heat-shocked bovine uterine cells. Such connection between cyclooxygenase/prostaglandin E synthase gene expression and heat shock response was absent in heat-shocked MAC-T and BMEC (Table 2). Therefore, niacin might not regulate the heat shock response of mammary cells via prostaglandin production.

We found higher cell viability in betaine-treated BMEC at $8 \mathrm{~h}$ of culture in thermoneutral conditions, suggesting that the growth of BMEC was altered by betaine. Similar effects have been reported in other types of cells. Betaine treatment at doses of $5 \mathrm{~m} M$ and $50 \mathrm{~m} M$ improved colony-forming efficiencies of rabbit renal epithelial cells and canine renal cells, respectively (Yancey and Burg, 1990; Moriyama et al., 1991). The cell density of mouse embryonic fibroblast cells was increased with $10 \mathrm{~m} M$ betaine treatment (Petronini et al., 1992). Blocking betaine metabolism through betaine-homocysteine methyltransferase knock-down resulted in decreased numbers of murine embryonic cells and resulted in fetal resorption after the embryos were transferred (Lee et al., 2012). Betaine promoted the proliferation of human cervical cancer cells at low doses $(<5 \mathrm{mg} / \mathrm{mL})$ but inhibited cell growth at high doses ( $>5 \mathrm{mg} / \mathrm{mL}$; Guo et al., 2015). The proliferationassociated effects of betaine may be mediated by alterations of cell cycles (Guo et al., 2015).

In this study, betaine treatment attenuated apoptotic effects in BMEC exposed to heat stress. Another in vitro study indicated that betaine activated chaperonemediated refolding of native mitochondrial dehydrogenases and provided full protection from thermal denaturation at $44^{\circ} \mathrm{C}$ (Diamant et al., 2001). Mitochondrial dehydrogenase activity was the indicator of cell viability in this study. Taken together with the results of the previous study, our XTT assay findings suggest that betaine might act as a chemical chaperone to restore secondary structures of mitochondrial enzymes and keep them functional in mammary epithelial cells during heat stress. On the other hand, we found that betaine might protect BMEC from heat stress via antiapoptotic effects. Apoptosis in heat-shocked BMEC was observed here and has been reported before $\mathrm{Hu}$ et al., 2015). The expression of several pro- or antiapoptotic genes, including stress proteins heat shock proteins, was altered during heat-induced apoptosis in BMEC (Hu et al., 2015). In previous observations, we have found that betaine-treated BMEC exhibited a higher capacity for HSP 70 and HSP27 mRNA expression in heat stress (Hall et al., 2016). Both HSP70 and HSP27 are well known for their antiapoptotic effects by regulating apoptotic pathways with their co-chaperones (Takayama et al., 2003). Additionally, the major metabolite of betaine (methionine) has similar antiapoptotic effects in heat-shocked BMEC, including upregulation of HSP 70 and HSF1 and downregulation of Bax/ Bcl-2 and caspase-3 activity (Han et al., 2015). Thus, our data and previous studies support the hypothesis that betaine might protect mammary epithelial cells from heat-induced apoptosis by maintaining heat shock protein expression, which alters proapoptotic and antiapoptotic pathways.

One limitation of this study was that we used a single reference gene to normalize the mRNA abundance of genes of interest. Although a single selected reference gene shows stable expression across individuals, tissues, cells, or experimental treatments, it still can vary considerably (Vandesompele et al., 2002). Normalizations with multiple reference genes could more accurately reflect the mRNA abundance of the genes of interest (Vandesompele et al., 2002) and theoretically increase the probability of detecting statistical differences. Additionally, the mRNA expression patterns of all genes measured in this study were not verified at the protein level. Because mRNA abundance is not always highly and significantly correlated with the protein level (Gry et al., 2009; Maier et al., 2009), it is desirable to evalu- 
ate whether niacin and betaine exert similar effects on the protein abundance of heat shock protein during heat stress.

The present study revealed that bovine mammary tissues had abundant distribution of the niacin receptor GPR109A, and that niacin stimulated mRNA expression of $\mathrm{HSP}^{27}$ in heat-shocked mammary and uterine cells. Altered mRNA expression of $\mathrm{PGE}_{2}$ synthesis-related genes due to niacin treatment might be involved in these processes in uterine cells, but might not be involved in mammary cells. Betaine exhibited transient proliferative and protective effects in mammary epithelial cells under normal and heat stress conditions, respectively. These data suggested positive roles for niacin and betaine as feed supplements on improving the function of the bovine uterus and udders in the summer.

\section{ACKNOWLEDGMENTS}

We thank Wendie S. Cohick (Rutgers, the State University of New Jersey, New Brunswick) and Thomas R. Hansen (Colorado State University, Fort Collins) for providing the cell lines used to perform this study. We thank the Department of Agriculture, Australia, for the funding to conduct this study.

\section{REFERENCES}

Annen, E. L., A. C. Fitzgerald, P. C. Gentry, M. A. McGuire, A. V. Capuco, L. H. Baumgard, and R. J. Collier. 2007. Effect of continuous milking and bovine somatotropin supplementation on mammary epithelial cell turnover. J. Dairy Sci. 90:165-183.

Beede, D. K., and R. J. Collier. 1986. Potential nutritional strategies for intensively managed cattle during thermal stress. J. Anim. Sci. 62:543-554.

Bermudez, Y., C. A. Benavente, R. G. Meyer, W. R. Coyle, M. K. Jacobson, and E. L. Jacobson. 2011. Nicotinic acid receptor abnormalities in human skin cancer: Implications for a role in epidermal differentiation. PLoS One 6:e20487.

Bissell, M. J., A. Rizki, and I. S. Mian. 2003. Tissue architecture: The ultimate regulator of breast epithelial function. Curr. Opin. Cell Biol. 15:753-762.

Bundy, L. M., and L. Sealy. 2003. CCAAT/enhancer binding protein beta (C/EBPbeta)-2 transforms normal mammary epithelial cells and induces epithelial to mesenchymal transition in culture. Oncogene 22:869-883.

Collier, R. J., J. L. Collier, R. P. Rhoads, and L. H. Baumgard. 2008 Invited review: Genes involved in the bovine heat stress response. J. Dairy Sci. 91:445-454.

Collier, R. J., C. M. Stiening, B. C. Pollard, M. J. VanBaale, L. H. Baumgard, P. C. Gentry, and P. M. Coussens. 2006. Use of gene expression microarrays for evaluating environmental stress tolerance at the cellular level in cattle. J. Anim. Sci. 84(E. Suppl.):E1E13.

Craig, S. A. 2004. Betaine in human nutrition. Am. J. Clin. Nutr. 80:539-549.

Dearth, L. R., J. Hutt, A. Sattler, A. Gigliotti, and J. DeWille. 2001. Expression and function of CCAAT/enhancer binding proteinbeta (C/EBPbeta) LAP and LIP isoforms in mouse mammary gland, tumors and cultured mammary epithelial cells. J. Cell. Biochem. 82:357-370.
Di Costanzo, A., J. N. Spain, and D. E. Spiers. 1997. Supplementation of nicotinic acid for lactating Holstein cows under heat stress conditions. J. Dairy Sci. 80:1200-1206.

Diamant, S., N. Eliahu, D. Rosenthal, and P. Goloubinoff. 2001 Chemical chaperones regulate molecular chaperones in vitro and in cells under combined salt and heat stresses. J. Biol. Chem. 276:39586-39591.

DiGiacomo, K., S. Simpson, B. J. Leury, and F. R. Dunshea. 2016. Dietary betaine impacts the physiological responses to moderate heat conditions in a dose dependent manner in sheep. Animal 6:51.

DiGiacomo, K., R. D. Warner, B. J. Leury, J. B. Gaughan, and F. R. Dunshea. 2014. Dietary betaine supplementation has energy-sparing effects in feedlot cattle during summer, particularly in those without access to shade. Anim. Prod. Sci. 54:450-458.

Dufva, G. S., E. E. Bartley, A. D. Dayton, and D. O. Riddell. 1983. Effect of niacin supplementation on milk production and ketosis of dairy cattle. J. Dairy Sci. 66:2329-2336.

Dunshea, F. R., B. J. Leury, F. Fahri, K. DiGiacomo, A. Hung, S. Chauhan, I. J. Clarke, R. J. Collier, S. Little, L. H. Baumgard, and J. B. Gaughan. 2013. Amelioration of thermal stress impacts in dairy cows. Anim. Prod. Sci. 53:965-975.

Elangovan, S., R. Pathania, S. Ramachandran, S. Ananth, R. N. Padia, L. Lan, N. Singh, P. M. Martin, L. Hawthorn, P. D. Prasad, V. Ganapathy, and M. Thangaraju. 2014. The niacin/butyrate receptor GPR109A suppresses mammary tumorigenesis by inhibiting cell survival. Cancer Res. 74:1166-1178.

Fujimori, K., and F. Amano. 2011. Niacin promotes adipogenesis by reducing production of anti-adipogenic PGF2alpha through suppression of C/EBPbeta-activated COX-2 expression. Prostaglandins Other Lipid Mediat. 94:96-103.

Gebremedhin, K. G., P. E. Hillman, C. N. Lee, R. J. Collier, S. T. Willard, J. D. Arthington, and T. M. Brown-Brandl. 2008. Sweating rates of dairy cows and beef heifers in hot conditions. Trans. ASABE 51:2167-2178.

Gille, A., E. T. Bodor, K. Ahmed, and S. Offermanns. 2008. Nicotinic acid: Pharmacological effects and mechanisms of action. Annu. Rev. Pharmacol. Toxicol. 48:79-106.

Graff, E. C., O. C. Norris, M. Sandey, R. J. Kemppainen, and R. L. Judd. 2015. Characterization of the hydroxycarboxylic acid receptor 2 in cats. Domest. Anim. Endocrinol. 53:88-94.

Greene, J. M., Z. Larin, I. C. Taylor, H. Prentice, K. A. Gwinn, and R. E. Kingston. 1987. Multiple basal elements of a human hsp70 promoter function differently in human and rodent cell lines. Mol. Cell. Biol. 7:3646-3655.

Gry, M., R. Rimini, S. Strömberg, A. Asplund, F. Pontén, M. Uhlén, and P. Nilsson. 2009. Correlations between RNA and protein expression profiles in 23 human cell lines. BMC Genomics 10:365.

Guo, Y., L. S. Xu, D. Zhang, Y. P. Liao, H. P. Wang, Z. H. Lan, W. J. Guan, and C. Q. Liu. 2015. Betaine effects on morphology, proliferation, and p53-induced apoptosis of HeLa cervical carcinoma cells in vitro. Asian Pac. J. Cancer Prev. 16:3195-3201.

Hall, L. W., F. R. Dunshea, J. D. Allen, S. Rungruang, J. L. Collier, N. M. Long, and R. J. Collier. 2016. Evaluation of dietary betaine in lactating Holstein cows subjected to heat stress. J. Dairy Sci. 99:9745-9753.

Han, Z. Y., T. Mu, and Z. Yang. 2015. Methionine protects against hyperthermia-induced cell injury in cultured bovine mammary epithelial cells. Cell Stress Chaperones 20:109-120.

Hanson, J., A. Gille, S. Zwykiel, M. Lukasova, B. E. Clausen, K. Ahmed, S. Tunaru, A. Wirth, and S. Offermanns. 2010. Nicotinic acid- and monomethyl fumarate-induced flushing involves GPR109A expressed by keratinocytes and COX-2-dependent prostanoid formation in mice. J. Clin. Invest. 120:2910-2919.

Hassan, R. A., T. A. Ebeid, A. I. Abd El-Lateif, and N. B. Ismail. 2011. Effect of dietary betaine supplementation on growth, carcass and immunity of New Zealand White rabbits under high ambient temperature. Livest. Sci. 135:103-109.

Healy, Z. R., F. Zhu, J. D. Stull, and K. Konstantopoulos. 2008. Elucidation of the signaling network of COX-2 induction in sheared chondrocytes: COX-2 is induced via a Rac/MEKK1/MKK7/ 
JNK2/c-Jun-C/EBPbeta-dependent pathway. Am. J. Physiol. Cell Physiol. 294:C1146-C1157.

Hernandez, L. L., S. W. Limesand, J. L. Collier, N. D. Horseman, and R. J. Collier. 2009. The bovine mammary gland expresses multiple functional isoforms of serotonin receptors. J. Endocrinol. 203:123-131.

Hernandez, L. L., C. M. Stiening, J. B. Wheelock, L. H. Baumgard, A. M. Parkhurst, and R. J. Collier. 2008. Evaluation of serotonin as a feedback inhibitor of lactation in the bovine. J. Dairy Sci. 91:1834-1844.

Hu, H., J. Wang, H. Gao, S. Li, Y. Zhang, and N. Zheng. 2015. Heatinduced apoptosis and gene expression in bovine mammary epithelial cells. Anim. Prod. Sci. 56:918-926.

Huyck, L., C. Ampe, and M. Van Troys. 2012. The XTT cell proliferation assay applied to cell layers embedded in three-dimensional matrix. Assay Drug Dev. Technol. 10:382-392.

Huynh, H. T., G. Robitaille, and J. D. Turner. 1991. Establishment of bovine mammary epithelial cells (MAC-T): An in vitro model for bovine lactation. Exp. Cell Res. 197:191-199.

Jaster, E. H. and N. E. Ward. 1990. Supplemental nicotinic acid or nicotinamide for lactating dairy cows. J. Dairy Sci. 73:2880-2887.

Kozawa, O., T. Otsuka, D. Hatakeyama, M. Niwa, H. Matsuno, H Ito, K. Kato, N. Matsui, and T. Uematsu. 2001. Mechanism of prostaglandin $\mathrm{D}(2)$-stimulated heat shock protein 27 induction in osteoblasts. Cell. Signal. 13:535-541.

Kung, L. Jr., K. Gubert, and J. T. Huber. 1980. Supplemental niacin for lactating cows fed diets of natural protein or nonprotein nitrogen. J. Dairy Sci. 63:2020-2025.

Lee, M. B., M. Kooistra, B. Zhang, S. Slow, A. L. Fortier, T. A Garrow, M. Lever, J. M. Trasler, and J. M. Baltz. 2012. Betaine homocysteine methyltransferase is active in the mouse blastocyst and promotes inner cell mass development. J. Biol. Chem. 287:33094-33103

Lee, Y. S., V. Terzidou, T. Lindstrom, M. Johnson, and P. R. Bennett. 2005. The role of CCAAT/enhancer-binding protein beta in the transcriptional regulation of COX-2 in human amnion. Mol. Hum. Reprod. 11:853-858.

Lever, M., and S. Slow. 2010. The clinical significance of betaine, an osmolyte with a key role in methyl group metabolism. Clin. Biochem. 43:732-744.

Li, L., Y. Sun, J. Wu, X. Li, M. Luo, and G. Wang. 2015. The globa effect of heat on gene expression in cultured bovine mammary epithelial cells. Cell Stress Chaperones 20:381-389.

Livak, K. J., and T. D. Schmittgen. 2001. Analysis of relative gene expression data using real-time quantitative PCR and the 2(-Delta Delta C(T)). Methods 25:402-408.

Lohölter, M., U. Meyer, C. Rauls, J. Rehage, and S. Dänicke. 2013 Effects of niacin supplementation and dietary concentrate proportion on body temperature, ruminal $\mathrm{pH}$ and milk performance of primiparous dairy cows. Arch. Anim. Nutr. 67:202-218.

Macias, H., and L. Hinck. 2012. Mammary gland development. Wiley Interdiscip. Rev. Dev. Biol. 1:533-557.

Maciejewski-Lenoir, D., J. G. Richman, Y. Hakak, I. Gaidarov, D. P. Behan, and D. T. Connolly. 2006. Langerhans cells release prostaglandin D2 in response to nicotinic acid. J. Invest. Dermatol. 126:2637-2646.

Maier, T., M. Güell, and L. Serrano. 2009. Correlation of mRNA and protein in complex biological samples. FEBS Lett. 583:3966-3973.

McGrath, M. F. 1987. A novel system for mammary epithelial cell culture. J. Dairy Sci. 70:1967-1980.

Moriyama, T., A. Garcia-Perez, A. D. Olson, and M. B. Burg. 1991. Intracellular betaine substitutes for sorbitol in protecting renal medullary cells from hypertonicity. Am. J. Physiol. 260:F494F497.

Muller, L. D., A. J. Heinrichs, J. B. Cooper, and Y. H. Atkin. 1986. Supplemental niacin for lactating cows during summer feeding. J. Dairy Sci. 69:1416-1420.

Offermanns, S., S. L. Colletti, T. W. Lovenberg, G. Semple, A. Wise, and A. P. Ijzerman. 2011. International Union of Basic and Clinical Pharmacology. LXXXII: Nomenclature and classification of hydroxy-carboxylic acid receptors (GPR81, GPR109A, and GPR109B). Pharmacol. Rev. 63:269-290.

Peterson, S. E., P. Rezamand, J. E. Williams, W. Price, M. Chahine, and M. A. McGuire. 2012. Effects of dietary betaine on milk yield and milk composition of mid-lactation Holstein dairy cows. J. Dairy Sci. 95:6557-6562.

Petronini, P. G., E. M. De Angelis, A. F. Borghetti, and K. P. Wheeler. 1993. Effect of betaine on HSP70 expression and cell survival during adaptation to osmotic stress. Biochem. J. 293:553-558.

Petronini, P. G., E. M. De Angelis, P. Borghetti, A. F. Borghetti, and K. P. Wheeler. 1992. Modulation by betaine of cellular responses to osmotic stress. Biochem. J. 282:69-73.

Pineda, A., J. K. Drackley, J. Garrett, and F. C. Cardoso. 2016. Effects of rumen-protected niacin on milk production and body temperature of middle and late lactation Holstein cows. Livest. Sci. 187:16-23.

Rahman, M., S. Muhammad, M. A. Khan, H. Chen, D. A. Ridder, H. Muller-Fielitz, B. Pokorna, T. Vollbrandt, I. Stolting, R. Nadrowitz, J. G. Okun, S. Offermanns, and M. Schwaninger. 2014. The beta-hydroxybutyrate receptor HCA2 activates a neuroprotective subset of macrophages. Nat. Commun. 5:3944.

Rhoads, R. P., L. H. Baumgard, J. K. Suagee, and S. R. Sanders. 2013. Nutritional interventions to alleviate the negative consequences of heat stress. Adv. Nutr. 4:267-276.

Roehm, N. W., G. H. Rodgers, S. M. Hatfield, and A. L. Glasebrook. 1991. An improved colorimetric assay for cell proliferation and viability utilizing the tetrazolium salt XTT. J. Immunol. Methods $142: 257-265$.

Rungruang, S., J. L. Collier, R. P. Rhoads, L. H. Baumgard, M. J. de Veth, and R. J. Collier. 2014. A dose-response evaluation of rumen-protected niacin in thermoneutral or heat-stressed lactating Holstein cows. J. Dairy Sci. 97:5023-5034.

Saint-Dizier, M., C. Guyader-Joly, G. Charpigny, B. Grimard, P. Humblot, and A. A. Ponter. 2011. Expression of enzymes involved in the synthesis of prostaglandin E2 in bovine in vitro-produced embryos. Zygote 19:277-283.

Schwab, E. C., D. Z. Caraviello, and R. D. Shaver. 2005. Review: A meta-analysis of lactation responses to supplemental dietary niacin in dairy cows. Prof. Anim. Sci. 21:239-247.

Seagroves, T. N., S. Krnacik, B. Raught, J. Gay, B. Burgess-Beusse, G. J. Darlington, and J. M. Rosen. 1998. C/EBPbeta, but not $\mathrm{C} / \mathrm{EBPalpha}$, is essential for ductal morphogenesis, lobuloalveolar proliferation, and functional differentiation in the mouse mammary gland. Genes Dev. 12:1917-1928.

Sivaprasad, U., J. Fleming, P. S. Verma, K. A. Hogan, G. Desury, and W. S. Cohick. 2004. Stimulation of insulin-like growth factor (IGF) binding protein-3 synthesis by IGF-I and transforming growth factor-alpha is mediated by both phosphatidylinositol-3 kinase and mitogen-activated protein kinase pathways in mammary epithelial cells. Endocrinology 145:4213-4221.

Staggs, K. L., K. J. Austin, G. A. Johnson, M. G. Teixeira, C. T. Talbott, V. A. Dooley, and T. R. Hansen. 1998. Complex induction of bovine uterine proteins by interferon-tau. Biol. Reprod. 59:293-297.

Stiening, C. M., J. B. Hoying, M. B. Abdallah, A. M. Hoying, R. Pandey, K. Greer, and R. J. Collier. 2008. The effects of endocrine and mechanical stimulation on stage I lactogenesis in bovine mammary epithelial cells. J. Dairy Sci. 91:1053-1066.

Takayama, S., J. C. Reed, and S. Homma. 2003. Heat-shock protein as regulators of apoptosis. Oncogene 22:9041-9047.

Tao, S., J. W. Bubolz, B. C. do Amaral, I. M. Thompson, M. J. Hayen, S. E. Johnson, and G. E. Dahl. 2011. Effect of heat stress during the dry period on mammary gland development. J. Dairy Sci. 94:5976-5986.

Titgemeyer, E. C., L. K. Mamedova, K. S. Spivey, J. K. Farney, and B J. Bradford. 2011. An unusual distribution of the niacin receptor in cattle. J. Dairy Sci. 94:4962-4967.

Tokuda, H., O. Kozawa, M. Niwa, H. Matsuno, K. Kato, and T. Uematsu. 2002. Mechanism of prostaglandin E2-stimulated heat shock protein 27 induction in osteoblast-like MC3T3-E1 cells. J. Endocrinol. 172:271-281. 
Vandesompele, J., K. De Preter, F. Pattyn, B. Poppe, N. Van Roy, A. De Paepe, and F. Speleman. 2002. Accurate normalization of real-time quantitative RT-PCR data by geometric averaging of multiple internal control genes. Genome Biol. 3:RESEARCH0034

West, J. W. 2003. Effects of heat-stress on production in dairy cattle. J. Dairy Sci. 86:2131-2144.

Wise, A., S. M. Foord, N. J. Fraser, A. A. Barnes, N. Elshourbagy, M. Eilert, D. M. Ignar, P. R. Murdock, K. Steplewski, A. Green, A. J. Brown, S. J. Dowell, P. G. Szekeres, D. G. Hassall, F. H. Marshall, S. Wilson, and N. B. Pike. 2003. Molecular identification of high and low affinity receptors for nicotinic acid. J. Biol. Chem. 278:9869-9874.

Wozniak, M. A., R. Desai, P. A. Solski, C. J. Der, and P. J. Keely. 2003. ROCK-generated contractility regulates breast epithelial cell differentiation in response to the physical properties of a threedimensional collagen matrix. J. Cell Biol. 163:583-595.

Wu, C. 1995. Heat shock transcription factors: Structure and regulation. Annu. Rev. Cell Dev. Biol. 11:441-469.

Yancey, P. H., and M. B. Burg. 1990. Counteracting effects of urea and betaine in mammalian cells in culture. Am. J. Physiol. 258:R198R204.
Yuan, J. S., A. Reed, F. Chen, and C. N. Jr. Stewart. 2006. Statistical analysis of real-time PCR data. BMC Bioinformatics 7:85.

Yuan, K., R. D. Shaver, M. Espineira, and S. J. Bertics. 2011. Effect of a rumen-protected niacin product on lactation performance by dairy cows during summer in Wisconsin. Prof. Anim. Sci. 27:190194.

Zhang, L., S. J. Ying, W. J. An, H. Lian, G. B. Zhou, and Z. Y. Han. 2014. Effects of dietary betaine supplementation subjected to heat stress on milk performances and physiology indices in dairy cow. Genet. Mol. Res. 13:7577-7586.

Zimbelman, R. B., L. H. Baumgard, and R. J. Collier. 2010. Effects of encapsulated niacin on evaporative heat loss and body temperature in moderately heat-stressed lactating Holstein cows. J. Dairy Sci. 93:2387-2394.

Zimbelman, R. B., R. J. Collier, and T. R. Bilby. 2013. Effects of utilizing rumen protected niacin on core body temperature as well as milk production and composition in lactating dairy cows during heat stress. Anim. Feed Sci. Technol. 180:26-33. 